\title{
The Fate of Xylella fastidiosa in Vineyard Weeds and Other Alternate Hosts in California
}

\author{
C. Wistrom and A. H. Purcell, Department of Environmental Science, Policy and Management, University of Cali-
} fornia, Berkeley 94720-3114

\begin{abstract}
Wistrom, C., and Purcell, A. H. 2005. The fate of Xylella fastidiosa in vineyard weeds and other alternate hosts in California. Plant Dis. 89:994-999.

The fate of Xylella fastidiosa, the bacterium that causes Pierce's disease of grape, was assessed in 29 species of plants associated with vineyards in California's San Joaquin Valley. Bacterial populations and movement in greenhouse-grown plants were measured 1,3, and 9 weeks after mechanical and insect inoculation. X. fastidiosa was recovered in 27 of 29 species in greenhouse tests, with common sunflower (Helianthus annuus), cocklebur (Xanthium strumarium), annual bur-sage (Ambrosia acanthicarpa), morning glory (Ipomoea purpurea), horseweed (Conyza canadensis), sacred datura (Datura wrightii), poison hemlock (Conium maculatum), and fava bean (Vicia faba cv. Aquadulce) being infected in more than $50 \%$ of inoculation attempts. Twenty-three species supported bacterial populations in excess of $10^{4} \mathrm{CFU} / \mathrm{g}$ of plant tissue. $X$. fastidiosa populations increased for 9 weeks after inoculation in six species, and were static or declined in 16 species. Although the blue-green sharpshooter (Graphocephala atropunctata) was more efficient than mechanical inoculation for infecting plants, median populations and systemic movement for the two methods did not differ significantly. $X$. fastidiosa colonization of greenhouse and field-grown plants was compared in five alternate hosts. X. fastidiosa was recovered from 23 and 34\% of field-grown plants, compared with 49 and $67 \%$ of greenhouse-grown plants, in the winter and summer, respectively, with at least 10 times fewer bacteria in field plants in the winter. Although $X$. fastidiosa has a wide host plant range, its fate in most species is variable and heavily influenced by field conditions.
\end{abstract}

Additional keywords: glassy-winged sharpshooter, Homalodisca coagulata

Pierce's disease of grapevine (Vitis vinifera) is caused by Xylella fastidiosa, a bacterium transmitted by xylem sapfeeding sharpshooter leafhoppers and spittlebugs $(21,28,30,31)$. In California, epidemiologically important vectors of Pierce's disease vary by region and include glassy-winged sharpshooters (Homalodisca coagulata) in southern California and the lower San Joaquin Valley, redheaded sharpshooters (Xyphon [Carneocephala] fulgida) and green sharpshooters (Draeculacephala minerva) throughout the San Joaquin Valley, and blue-green sharpshooters (Graphocephala atropunctata) along the coast $(2,4)$. The detection of $X$. fastidiosa in D. minerva and $X$. fulgida from diverse habitats, including areas remote from cultivated crops, indicates that sharpshooters may acquire this pathogen from diverse feeding hosts (12). However, the fate of $X$. fastidiosa in common weedy plant species in the southern San Joaquin Valley of California has not been established.

Corresponding author: Alexander H. Purcell

E-mail: purcell@ nature.berkeley.edu

Accepted for publication 20 April 2005.

DOI: 10.1094/PD-89-0994

(C) 2005 The American Phytopathological Society
In early insect-transmission studies with sharpshooter vectors, the Pierce's disease agent was transmitted to and recovered from 75 species of plants in greenhouse tests using insect acquisition and inoculation of the pathogen, although pathogen detection was solely based on symptom expression in alfalfa (Medicago sativa) and grapes (11). More accurate detection of $X$. fastidiosa in numerous species of natural vegetation became possible once serological and culture techniques were developed $(6,20,27)$. Studies of the fate of $X$. fastidiosa in four plant species highly preferred by insect vectors revealed that the bacteria multiplied in blackberry (Rubus discolor), mugwort (Artemisia douglasiana), and watergrass (Echinochloa crusgalli), but not in bermudagrass (Cynodon dactylon). Only blackberry supported systemic bacterial movement throughout the plant (16). Further examination of the fate of $X$. fastidiosa in 33 species of riparian plants commonly found in Napa Valley confirmed that $X$. fastidiosa could multiply in most plant species, but often failed to move systemically beyond the inoculation site, suggesting infections eventually died out in nonsystemic hosts (26). Systemic movement is correlated with bacterial population $(16,26)$, which in turn relates to vector acquisition efficiency (17).
Subfreezing temperatures influence $X$. fastidiosa overwinter survival in a given host plant (23). Moreover, temperatures regulate growth of $X$. fastidiosa in plants. For example, extremely cold temperatures can eliminate $X$. fastidiosa infections and determine the geographic distribution of $X$. fastidiosa (18). Pierce's disease-infected grapes were cured of $X$. fastidiosa infections in proportion to cold severity in laboratory and field experiments (23). Optimum temperatures for $X$. fastidiosa growth in planta were between 17 and $34^{\circ} \mathrm{C}$, and bacterial populations remained static or decreased at temperatures above $34^{\circ} \mathrm{C}$ and below $17^{\circ} \mathrm{C}(10)$.

Our objectives were to (i) determine the fate of $X$. fastidiosa infections in previously untested plant species associated with southern San Joaquin Valley vineyards, and (ii) compare survival of $X$. fastidiosa infections in selected field and greenhouse-grown plants.

\section{MATERIALS AND METHODS}

Selection and propagation of plants to be tested. Plant species were selected for testing with input from farm advisors and the Kern-Tulare Glassy-winged Sharpshooter/Pierce's Disease Task Force. Plants were ranked by priority. Perennials and known feeding and oviposition hosts of the glassy-winged sharpshooter were tested first, then plants particularly abundant in or near vineyards (University of California Davis IPM online). Plants were grown in the greenhouse from field-collected seed, except for field bindweed (Convolvulus arvensis) and yellow nutsedge (Cyperus esculentus), which were vegetatively propagated from field-collected stems. Red gum (Eucalyptus camaldulensis) and blue gum (Eucalyptus globulus) were obtained as commercial nursery plants. Plants were grown in University of California (U.C.) Davis Mix (equal parts coarse sand, peat moss, and nitrolyzed redwood sawdust) in a greenhouse at U.C. Berkeley maintained at $25^{\circ} \mathrm{C}$ $\left(+10^{\circ} \mathrm{C} /-5^{\circ} \mathrm{C}\right)$ and fertilized daily with dilute Hoagland's solution and monthly with 20-20-20 fertilizer at the label rate (8). Plants were grown with natural light conditions. Scientific and common names are listed according to the Jepson Manual (14) and the Growers Weed Identification Handbook (3). Voucher specimens were deposited in the Jepson Herbarium at U.C. Berkeley. 
Inoculation and detection of $X$. fastidiosa under greenhouse conditions. All plants were inoculated with the STL strain of $X$. fastidiosa (13), a grape strain from Napa County, CA. Plants were inoculated with $X$. fastidiosa via needle puncture or by the sharpshooters $H$. coagulata, $X$. fulgida, and $G$. atropunctata. All species inoculated with $H$. coagulata were also inoculated with $G$. atropunctata, with the exception of tree tobacco (Nicotiana glauca) and red gum, which were needle inoculated because $G$. atropunctata could not survive the inoculation access period. Ten to 115 plants were inoculated in at least two replications per species. Plants were maintained in a greenhouse at U.C. Berkeley as previously described.

The sharpshooter species selected depended on its preferred host plants in the field (28). Grasses were inoculated with $X$. fulgida; perennial and woody species were inoculated with $H$. coagulata; and herbaceous annuals were inoculated with $G$. atropunctata. To account for differences in inoculation efficiency between sharpshooter species, we only used data from insect groups that transmitted $X$. fastidiosa to grapes prior to exposure to alternate hosts. Insects acquired X. fastidiosa from infected grapevines in a 4-day acquisition access period and then were tested for presence of $X$. fastidiosa with a 4-day inoculation access period on a seedling grape (cv. Cabernet Sauvignon or Pinot Noir). Insects were then confined to plants in groups of two to four in small foam cages for 2 days (17). The cages were located on young, nonlignified, fully expanded stems, leaves, or petioles, where the plant was strong enough to support the weight of the cage. For example, prickly lettuce (Lactuca serriola) was inoculated on caudal leaves, poison hemlock (Conium maculatum) on basal petioles, and fava bean (Vicia faba cv. Aquadulce), red gum, cocklebur (Xanthium strumarium), and common sunflower (Helianthus annuus) on green stems.

For needle inoculation, $10 \mu \mathrm{l}$ of $X$. fastidiosa cells suspended in succinatecitrate-phosphate buffer (approximately $10^{9} \mathrm{CFU} / \mathrm{ml}$ ) were deposited on a stem, petiole, or leaf. The plant was probed three to six times through the drop with a no. 2 insect pin until the suspension was drawn into the plant (16). All inoculation suspensions were tested for viability, and inoculations were performed on sunny days so that active transpiration aided uptake of the bacterial suspension (33).

$X$. fastidiosa was isolated from inoculated plants by culture on periwinkle wiltGelrite media $(7,16)$. Briefly, a section of plant was surface disinfested in successive rinses in $70 \%$ ethanol, $30 \%$ bleach $(1.5 \%$ sodium hypochlorite), and sterile water. The plant material was chopped on sterile Whatman no. 1 filter paper and placed in 2 $\mathrm{ml}$ of succinate-citrate-phosphate buffer. The sample was ground by a Polytron ho- mogenizer with a PT10/35 generator (Brinkmann Instruments, Westbury, NY) and diluted 100 -fold in succinate-citratephosphate buffer. Twenty microliters of each dilution were plated on modified periwinkle wilt media. Plates were incubated inverted for 7 to 14 days at $28^{\circ} \mathrm{C}$ in the dark.

The inoculation site was assayed for bacteria 1, 3, and 9 weeks after inoculation, as previous studies indicated that $X$. fastidiosa died out after 3 weeks in some hosts (26). We tested a secondary stem or leaf distal to the inoculation site to detect possible systemic movement of $X$. fastidiosa, where $X$. fastidiosa recovered from distal petioles or secondary stems passed between pits to colonize the plant (33). Three uninoculated plants belonging to the same cohort were kept in the greenhouse or field and tested along with the inoculated plants to test for accidental X. fastidiosa presence during inoculation and culturing. The presence of plant inhibitors to $X$. fastidiosa growth in vitro was evaluated by homogenizing uninfected plants of each species, adding $20 \mu \mathrm{l}$ of cultured $X$. fastidiosa cells suspended in succinatecitrate-phosphate buffer, then culturing the mixture (26). It was assumed that $X$. fastidiosa population estimates obtained by culturing were reasonable indicators of a plant's ability to be a host of bacteria for insect vector acquisition. Culturing detects $X$. fastidiosa in infected grapevines below $10^{4} \mathrm{CFU} / \mathrm{g}$, the threshold population required for acquisition by $G$. atropunctata, an efficient vector (17).

Field experiments. We selected seasonally appropriate plant species previously identified as having a high rate $(>50 \%)$ of systemic infection in greenhouse tests. We tested poison hemlock, a winter annual weed, and fava bean, a cover crop, in two replications from November 2001 to March 2002, and two summer annual weeds, common sunflower and cocklebur, in two replications between July and November 2002. Prickly lettuce, a long-lived winter annual, was included in both winter and summer tests. Plants were reared and inoculated in the greenhouse as previously described, except that groups of three $G$. atropunctata were allowed a 3-day inoculation access period, to allow a more reasonable planting and processing schedule with minimal overall effect on sharpshooter infectivity (24). In the second replication from November 2001 to March 2002, one-third of the plants of each species were mechanically inoculated due to lack of sharpshooters. Half the plants were kept in the greenhouse at U.C. Berkeley and the other half were planted in a screen house in Bakersfield, CA. Plants were assayed for $X$. fastidiosa by culturing at 1 , 3 , and 9 weeks after inoculation. Temperatures in the screen house were recorded with a portable Hobo temperature recorder (Onset Co., Pocasset, MA) and supplemented with field station temperature data from Arvin, CA (17 km away) for one experiment where the temperature recording system failed.

Data analysis. Data analysis and statistical comparisons were made using Excel (Microsoft, Redmond, WA). Chi-square comparisons were used to compare transmission rates, with Yates' correction applied to any values less than 10 .

\section{RESULTS}

Greenhouse inoculations. We detected $X$. fastidiosa infections in eight plant species more than $50 \%$ of the time in replicated greenhouse tests (Table 1). These were common sunflower, cocklebur, annual bur-sage (Ambrosia acanthicarpa), common morning glory (Ipomoea purpurea), horseweed (Conyza canadensis), sacred datura (Datura wrightii), poison hemlock, and fava bean. Of these, common sunflower, annual bur-sage, sacred datura, poison hemlock, and fava bean had median $X$. fastidiosa populations in excess $10^{6}$ CFU/g. An additional 14 species became infected with $X$. fastidiosa 20 to $49 \%$ percent of the time (Table 1). Of these, yellow nutsedge, prickly lettuce, and tree tobacco had median populations greater than $10^{6}$ $\mathrm{CFU} / \mathrm{g}$.

The only species that showed in vitro inhibition of $X$. fastidiosa was blue gum. In two replications, homogenized tissues of blue gum completely inhibited $X$. fastidiosa growth in one experiment and reduced viability (CFU) 100-fold in a second replication. When inoculated by $H$. coagulata and $G$. atropunctata, however, 10 of 62 blue gum stems were positive for $X$. fastidiosa, and the median bacterial population was $8 \times 10^{5} \mathrm{CFU} / \mathrm{g}$.

White clover (Trifolium repens), red clover (T. pretense cv. Linden), alfalfa (cv. Moapa), and black nightshade (Solanum nigrum) had other unidentified bacteria obscure putative $X$. fastidiosa in culture. Contamination problems occurred in separate replications, and did not occur in other plant species tested on the same day.

We observed a decline in $X$. fastidiosa transmission by $G$. atropunctata one winter, from October 2002 to February 2003. Only 30\% (46 of 152 groups) transmitted compared with $91 \%$ (81 of 89 groups) from April to August 2002 and 134 of 147 (91\%) of sharpshooter groups used after April 2003. The previous winter (November 2001 to January 2002), 95\% (122 of 128 ) of G. atropunctata groups transmitted $X$. fastidiosa.

In six species, G. atropunctata transmitted $X$. fastidiosa to a greater percentage of plants than did needle inoculation. For example, infective insects transmitted to $84 \%$ ( 36 of 43 stems) of common morning glory plants, but only $24 \%$ (12 of 51) became colonized after mechanical inoculation $(P<0.01$, chi-square, Table 2$)$. We also detected significantly more frequent $X$. fastidiosa recovery from G. atropunc- 
tata-inoculated prickly lettuce, cocklebur, and quinoa (Chenopodium quinoa).

Needle inoculation was more efficient than $H$. coagulata inoculation in four other plants. In cheeseweed (Malva parviflora), $X$. fastidiosa infections developed at $51 \%$ (29 of 57) of needle-inoculated sites but only at $8 \%$ of $H$. coagulata-inoculated sites $(1$ of $12, P<0.01$, chi-square with Yates' correction). Similar results occurred for sacred datura (needle inoculation: 43 of 56; H. coagulata: 1 of $7, P<0.01$ ) and red gum (needle inoculation: 12 of $33 ; \mathrm{H}$. coagulata: 0 of $5, P>0.05$, not significant). When sharpshooter groups inoculated seedling grapes during a 4-day inoculation access period, $30 \%$ of $H$. coagulata groups transmitted $X$. fastidiosa, compared with $96 \%$ of G. atropunctata groups. H. coagulata were even less efficient at transmitting $X$. fastidiosa to hosts other than grapes.

Bacterial spread and multiplication over time. Results for nine representative high population, systemic hosts, and poor and moderate hosts are shown in Figure 1. Data are not shown for an additional 13 species. Among these 22 species, X. fastidiosa populations in infected plants peaked at 3 weeks at a median population of $2 \times 10^{6} \mathrm{CFU} / \mathrm{g}$, and were $9 \times 10^{4} \mathrm{CFU} / \mathrm{g}$ and $6 \times 10^{5} \mathrm{CFU} / \mathrm{g}$ at 1 and 9 weeks, respectively.

Populations increased over time in six species: field bindweed, yellow nutsedge, common sunflower, prickly lettuce, fava bean, and sacred datura. Populations were

Table 1. Xylella fastidiosa infections in greenhouse-grown plants following insect vector and needle inoculation

\begin{tabular}{|c|c|c|c|c|c|}
\hline Species & No. tested & No. infected ${ }^{\mathrm{a}}$ & $\mathrm{CFU} / \mathrm{g}^{\mathrm{b}}$ & No. systemic ${ }^{c}$ & Inoculation $^{\mathrm{d}}$ \\
\hline Annual bur-sage - Ambrosia acanthicarpa & 47 & 31 & 6.2 & $25 / 31$ & GW, BG, NI \\
\hline Annual sowthistle - Sonchus oleraceus & 31 & 6 & 4.1 & $1 / 6$ & GW, BG \\
\hline Blue gum - Eucalyptus globulus & 62 & 10 & 5.9 & $3 / 10$ & $\mathrm{GW}, \mathrm{BG}$ \\
\hline Cheeseweed - Malva parviflora & 69 & 21 & 3.8 & $9 / 14$ & GW, BG, NI \\
\hline Cocklebur - Xanthium strumarium & 111 & 65 & 5.5 & $40 / 65$ & $\mathrm{GW}, \mathrm{BG}, \mathrm{NI}$ \\
\hline Common morning glory - Iротоеа purpurea & 94 & 48 & 5.2 & $26 / 53$ & BG, NI \\
\hline Common purslane - Portulaca oleracea & 39 & 9 & 5.7 & $3 / 9$ & BG \\
\hline Common sunflower - Helianthus anпииs & 76 & 63 & 6.3 & $48 / 60$ & $\mathrm{GW}, \mathrm{BG}, \mathrm{NI}$ \\
\hline Curly dock - Rumex crispus & 25 & 11 & 5.7 & $1 / 9$ & BG \\
\hline Eggplant - Solanum melongea cv. Violeta lunga & 54 & 22 & 4.0 & $16 / 23$ & NI \\
\hline Fava bean - Vicia fava cv. Aquadulce & 67 & 46 & 6.7 & $26 / 45$ & BG \\
\hline Field bindweed - Convolvulus arvensis & 39 & 11 & 5.9 & $5 / 6$ & BG \\
\hline Horseweed - Conyza canadensis & 15 & 13 & 5.1 & $7 / 13$ & GW, BG \\
\hline Johnsongrass - Sorghum halepense & 62 & 14 & 4.7 & $2 / 14$ & RH, BG, GW \\
\hline Jojoba - Simmondsia chinensis & 115 & 8 & 4.2 & $3 / 8$ & $\mathrm{BG}, \mathrm{NI}$ \\
\hline Poison hemlock - Conium maculatum & 37 & 24 & 6.4 & $16 / 24$ & $\mathrm{BG}, \mathrm{NI}$ \\
\hline Prickly lettuce - Lactuca serriola & 110 & 48 & 6.4 & $15 / 46$ & $\mathrm{GW}, \mathrm{BG}, \mathrm{NI}$ \\
\hline Prostrate pigweed - Amaranthus blitoides & 13 & 1 & - & $1 / 1$ & $\mathrm{GW}, \mathrm{BG}$ \\
\hline Quinoa-Chenopodium quinoa & 79 & 25 & 3.6 & $9 / 25$ & GW, BG, NI \\
\hline Red gum - Eucalyptus camaldulensis & 37 & 12 & 4.8 & $5 / 12$ & GW, NI \\
\hline Sacred datura - Datura wrightii & 56 & 43 & 6.8 & $14 / 45$ & NI \\
\hline Southwestern cupgrass - Eriochloa gracilis & 22 & 5 & 2.8 & $3 / 5$ & BG \\
\hline Tomato - Lycopersicon esculentum cv. Ace & 82 & 35 & 5.1 & $20 / 27$ & $\mathrm{NI}$ \\
\hline Tree tobacco - Nicotiana glauca & 44 & 14 & 6.5 & $7 / 15$ & $\mathrm{GW}, \mathrm{NI}$ \\
\hline Watergrass - Echinochloa crus-galli & 10 & 1 & 5.4 & $1 / 1$ & RH \\
\hline Whitestem filaree - Erodium moschatum & 42 & 9 & 4.7 & $4 / 9$ & GW, BG, NI \\
\hline Yellow nutsedge-Cyperus esculentus & 76 & 34 & 6.2 & $2 / 20$ & $\mathrm{RH}, \mathrm{BG}$ \\
\hline
\end{tabular}

a Results combined from two to six replications cultured 1, 3, and 9 weeks after inoculation.

${ }^{\mathrm{b}}$ Median X. fastidiosa populations at inoculation site, $\log _{10}$ CFU per gram plant tissue, combined 1,3 , and 9 weeks.

${ }^{c}$ Systemic infections are $X$. fastidiosa recovery by culture from an adjacent stem or petiole distal to the inoculation site. In common morning glory and eggplant, more $X$. fastidiosa infections were detected systemically than at the inoculation site because $X$. fastidiosa was recovered from distal stems after the inoculated leaf senesced.

${ }^{\mathrm{d}}$ Inoculation by Homalodisca coagulata (glassy-winged sharpshooter: GW), Graphocephala atropunctata (blue-green sharpshooter: BG), Xyphon [Carneocephala] fulgida (red-headed sharpshooter: $\mathrm{RH}$ ), or needle inoculation (NI).

Table 2. Comparison of Xylella fastidiosa infection in Graphocephala atropunctata (blue-green sharpshooter: BG) and mechanically (NI: needle) inoculated greenhouse-grown plants

\begin{tabular}{lccccc}
\hline Plant & Inoc. & No. tested & No. infected (\%) & CFU/ga (range) & No. systemic ${ }^{\mathbf{b}}(\%)$ \\
\hline Jojoba & BG & 41 & $5(12)$ & $4.1(3.1-4.3)$ & $1 / 5(20)$ \\
Jojoba & NI & 74 & $3(4)$ & $5.3(4.1-6.4)$ & $2 / 3(67)$ \\
Prickly lettuce & BG & 56 & $* 35(63)$ & $6.4(2.9-8.0)$ & $8 / 33(24)$ \\
Prickly lettuce & NI & 54 & $* 13(24)$ & $6.3(3.7-8.2)$ & $7 / 19(37)$ \\
Cocklebur & BG & 71 & $* 54(76)$ & $5.5(2.5-7.1)$ & $33 / 54(61)$ \\
Cocklebur & NI & 32 & $* 11(34)$ & $4.3(2.5-5.8)$ & $7 / 11(64)$ \\
Ambrosia & BG & 27 & $21(78)$ & $6.3(3.4-7.3)$ & $16 / 21(76)$ \\
Ambrosia & NI & 19 & $10(53)$ & $6.2(2.6-7.2)$ & $9 / 10(90)$ \\
Common morning glory & BG & 43 & $* 36(84)$ & $5.4(3.5-7.4)$ & $19 / 36(53)$ \\
Common morning glory & NI & 51 & $12(24)$ & $4.8(3.4-6.6)$ & $7 / 17(41)$ \\
Poison hemlock & BG & 22 & $14(64)$ & $6.7(2.8-7.7)$ & $11 / 14(79)$ \\
Poison hemlock & NI & 15 & $* 12(50)$ & $6.3(3.9-7.1)$ & $5 / 10(50)$ \\
Quinoa & BG & 24 & $* 13(27)$ & $3.8(2.6-5.6)$ & $2 / 12(17)$ \\
Quinoa & NI & 49 & & $3.5(2.8-4.8)$ & $7 / 13(54)$ \\
\hline
\end{tabular}

a $X$. fastidiosa populations in $\log _{10}$ CFU per gram of plant tissue at inoculation site.

${ }^{\mathrm{b}}$ Systemic infections are $X$. fastidiosa recovery by culture from an adjacent stem or petiole distal to the inoculation site. In common morning glory and prickly lettuce, more $X$. fastidiosa infections were detected systemically than at the inoculation site because $X$. fastidiosa was recovered from distal stems after the inoculated leaf senesced.

$\mathrm{c} *=$ Numbers infected are significantly different between BG and NI inoculation $(P<0.05$, chi-square with Yates' correction). 
static in another six species: cheeseweed, cocklebur, annual bur-sage, common morning glory, quinoa, and tomato (Lycopersicon esculentum cv. Ace). Bacterial populations decreased or were undetectable in johnsongrass (Sorghum halepense), jojoba (Simmondsia chinensis), annual sowthistle (Sonchus oleraceus), southwestern cupgrass (Eriochloa gracilis), whitestem filaree (Erodium moschatum), curly dock (Rumex crispus), poison hemlock, blue gum, tree tobacco, and eggplant (Solanum melongea cv. Violeta lunga). Few X. fastidiosa infections moved into the plant beyond the inoculation site in plants with typical basal rosette morphology (curly dock, whitestem filaree, annual sowthistle, and poison hemlock), where basal leaves inoculated with $X$. fastidiosa senesced as the plant matured.

Comparison of $X$. fastidiosa infection in field versus greenhouse. There were fewer $X$. fastidiosa infections in fieldgrown plants compared with greenhousegrown plants for the 9-week sampling period in both summer and winter experiments (Fig. 2). Bacterial populations in field-grown plants were lower, and these plants had fewer systemic infections detected beyond the inoculation site (Table 3).

In winter annuals grown from November 2001 to March 2002, X. fastidiosa was recovered from $23 \%$ (26 of 114) of fieldgrown plants and 49\% (51 of 105) of greenhouse-grown plants. Median bacterial populations in field-grown plants were approximately 100 -fold lower $\left(2 \times 10^{6}\right.$ $\mathrm{CFU} / \mathrm{g}$ in the greenhouse and $3 \times 10^{4}$ $\mathrm{CFU} / \mathrm{g}$ in field-grown plants). We detected systemic movement of $X$. fastidiosa in $49 \%$ of infected plants in the greenhouse, but only in $12 \%$ of infected field-grown plants. Median X. fastidiosa populations increased in greenhouse-grown plants over the 9-week sampling period $\left(2 \times 10^{5}\right.$ $\mathrm{CFU} / \mathrm{g}$ at 1 week, $6 \times 10^{6} \mathrm{CFU} / \mathrm{g}$ at 3 weeks, and $1 \times 10^{8} \mathrm{CFU} / \mathrm{g}$ at 9 weeks), but decreased in field-grown plants $\left(8 \times 10^{3}\right.$ $\mathrm{CFU} / \mathrm{g}$ at 1 week, $1 \times 10^{5} \mathrm{CFU} / \mathrm{g}$ at 3 weeks, and $4 \times 10^{4} \mathrm{CFU} / \mathrm{g}$ at 9 weeks). During winter-spring field tests, most temperatures $(2,229 \mathrm{~h}$ of 2,789 total $\mathrm{h})$ in the screen cage at Bakersfield were below the growth threshold for X. fastidiosa, while greenhouse temperatures were set at $25^{\circ} \mathrm{C}$, near the optimum temperature for $X$. fastidiosa growth.

Results were similar from July to November 2002: field-grown plants were less-frequently infected than greenhousegrown plants. Over 9 weeks, $X$. fastidiosa was detected in $67 \%$ (75 of 112) of greenhouse-grown plants compared with $34 \%$ (28 of 83) of field-grown plants $(P<$ 0.001 , chi-square comparison). However, median $X$. fastidiosa populations in infected plants were not significantly different: $2 \times 10^{6} \mathrm{CFU} / \mathrm{g}$ in greenhouse plants compared with $6 \times 10^{5} \mathrm{CFU} / \mathrm{g}$ in fieldgrown plants (two-sample $t$ test, $n=90, P$ $=0.16)$. Systemic movement was detected in $51 \%$ (36 of 71) of infected greenhouse plants, but only in $26 \%$ ( 5 of $27, P<0.05$, chi-square with Yates correction) of infected field-grown plants. Greenhouse temperatures were more moderate than field temperatures in the summer-fall experiments $(2,501$ of $2,606 \mathrm{~h}$ between 17 and $34^{\circ} \mathrm{C}$ in greenhouse; 2,042 of 3,054 h were between 17 and $34^{\circ} \mathrm{C}$ in the field). Summer field site temperature data were

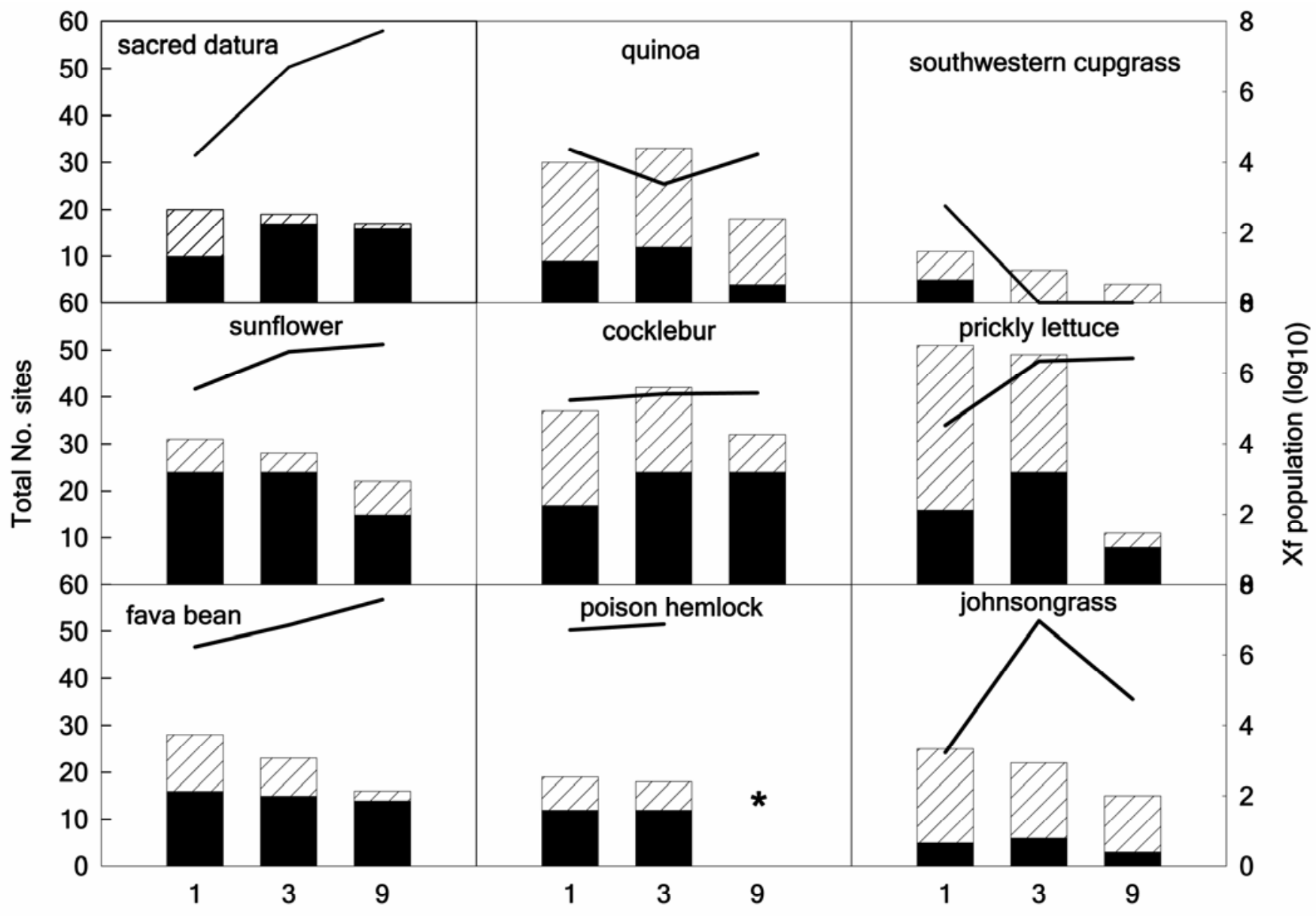

\section{Weeks after inoculation}

Fig. 1. Xylella fastidiosa infection in nine representative greenhouse-grown alternate hosts at 1,3 , and 9 weeks after inoculation. Black areas represent the number of sites with $X f$ recovery, and striped areas represent sites without $X$. fastidiosa. Populations (line, on the secondary $\mathrm{y}$-axis) are in log 10 CFU per gram of plant tissue. Sacred datura, common sunflower, cocklebur, prickly lettuce, and fava bean are examples of high population, frequently infected hosts. Quinoa and johnsongrass were infrequently infected and reached lower bacterial populations. Southwestern cupgrass was not a host after 1 week.

*All inoculation sites senesced from poison hemlock by 9 weeks. 
from Arvin station. Although $17 \mathrm{~km}$ from the field site, the two locations were geographically similar and had only a $1.1^{\circ} \mathrm{C}$ difference in comparisons of concurrent temperature data from both sites.

\section{DISCUSSION}

Our study confirmed that plant species cannot be simply classified as either "hosts" or "nonhosts" of X. fastidiosa but vary considerably among plant species in supporting growth and movement of the bacterium. In addition, environmental conditions have a major impact on bacterial growth in host plants. We propose that a good source plant for vector acquisition of $X$. fastidiosa has four characteristics: it must (i) be a feeding source for sharpshooters, (ii) frequently develop infections when inoculated by infective insects, (iii) allow systemic bacterial movement throughout the plant, and (iv) support high $X$. fastidiosa populations. The majority of the plants we tested met the first criterion. Both G. atropunctata and $H$. coagulata, typical of many xylem feeders, feed on an extremely wide range of plant species $(22,32)$ and can acquire $X$. fastidiosa after only a few hours of feeding on Pierce's diseased grapevines $(2,24)$. In our inoculation attempts, an average $77 \%$ of sharpshooters survived at least 2 days on the plants we tested, and even feeding access periods of a few hours are sufficient for vector acquisition of $X$. fastidiosa $(2,24)$. Both $G$. atropunctata and $H$. coagulata have adult life spans of many months $(29,32)$, which increases opportunities for the acquisition of $X$. fastidiosa from the variety of plants on which they feed.

Considerable interspecific variation was found for plants for the last three host criteria listed above. Our findings are similar to those of Freitag (11), Raju et al. (27), Hill and Purcell (16), and Purcell and Saunders (26), where most plants tested supported $X$. fastidiosa populations to some degree. However, our study also assessed $X$. fastidiosa populations at regular intervals after inoculation, and found that the plants tested supported three possible fates of $X$. fastidiosa infections: they increased over time (e.g., sacred datura), peaked at 6 weeks (johnsongrass), or remained static over the testing interval (cocklebur).

Inoculation efficiency varies between sharpshooter species $(2,28)$. In this study, sharpshooter inoculation with $G$. atropunctata was usually more efficient than needle inoculation for establishing $X$. fastidiosa infections in the plants we tested, while inoculation with $H$. coagulata was least efficient. However, the incidence of systemic infections detected in needleinoculated plants was often higher than for sharpshooter-inoculated plants. This should be considered when interpreting studies of systemic $X$. fastidiosa movement in plants.

Other factors that have been shown to influence the establishment and persistence of $X$. fastidiosa infection in almonds and grapes include bacterial strain, plant growth hormones, and pruning $(1,9,19)$, the sharpshooter species inoculating the plant, and field conditions and other environmental factors. Initial $X$. fastidiosa population may not affect the probability of colonization. Although $X$. fastidiosa

Table 3. Systemic movement of Xylella fastidiosa beyond the insect vector feeding site in hosts in the greenhouse and field in winter (November 2001 to March 2002) and summer (July to November 2002) $)^{\mathrm{a}}$

\begin{tabular}{lcccc}
\hline Plant & Season & Location & $\begin{array}{c}\text { No. systemic/ } \\
\text { no. infected }\end{array}$ & $\begin{array}{c}\text { CFU/gc } \\
\text { (median) }\end{array}$ \\
\hline Poison hemlock & Winter & GH & $16 / 24$ & 6.5 \\
Fava bean & Winter & Field & $0 / 12$ & $\ldots$ \\
Prickly lettuce & & GH & $5 / 15$ & 4.7 \\
& Winter & Field & $0 / 4$ & $\ldots$ \\
& & GH & $3 / 10$ & 2.5 \\
Common sunflower & Summer & Field & $3 / 9$ & 3.2 \\
& & GH & $5 / 24$ & 3.1 \\
Cocklebur & Summer & Field & $0 / 10$ & $\ldots$ \\
& & GH & $17 / 23$ & 5.5 \\
& Summer & Field & $2 / 5$ & 4.5 \\
& & GH & $14 / 24$ & 6.0 \\
\hline
\end{tabular}

a Alternate hosts were inoculated with $X$. fastidiosa by blue-green sharpshooters during 3 days in the greenhouse, then kept in the greenhouse $(\mathrm{GH})$ or planted outside (field) 1 day later. Populations are in $\log _{10}$ CFU per gram of plant material.

b Systemic infections are X. fastidiosa recovery by culture from an adjacent stem or petiole distal to the inoculation site.

${ }^{c}$ Median X. fastidiosa populations in $\log _{10}$ CFU per gram of plant tissue in an adjacent stem or petiole distal to the inoculation site.

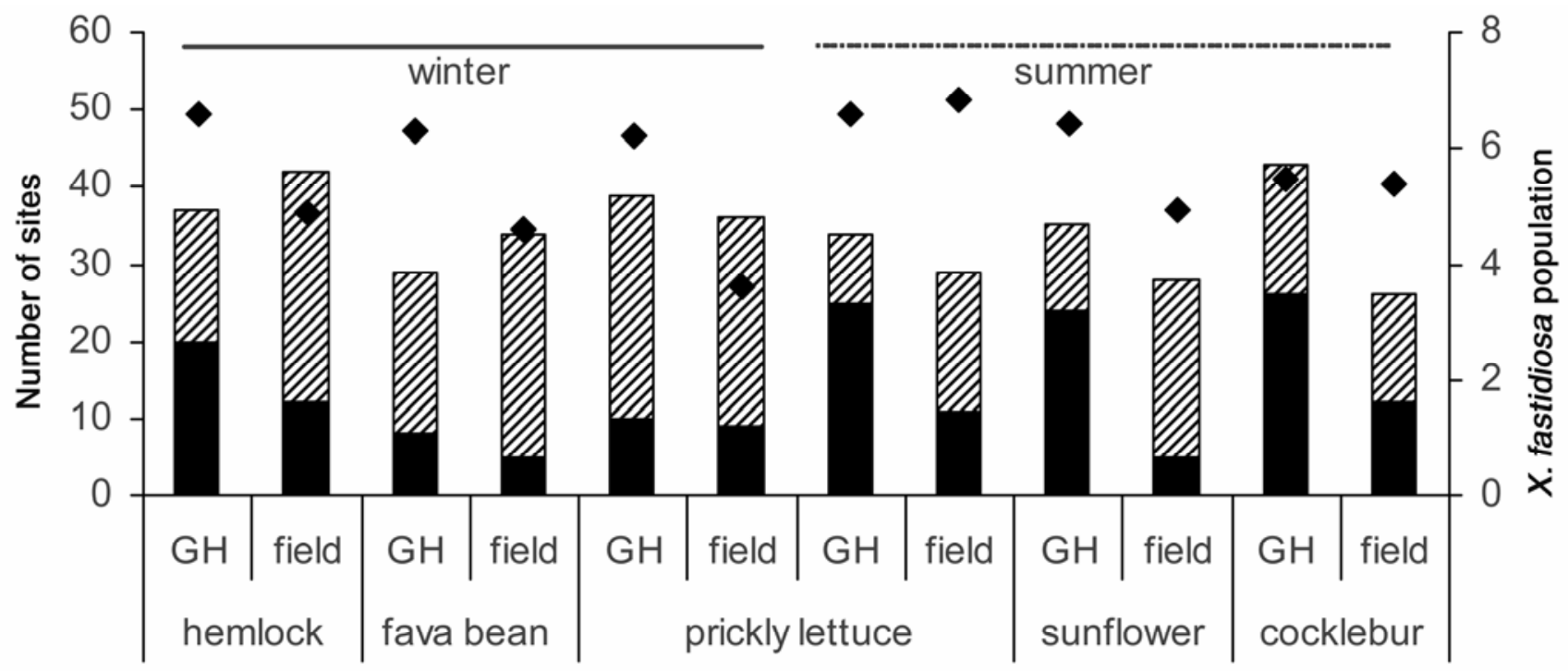

Alternate host and location

Fig. 2. Xylella fastidiosa infection at the caged insect feeding site in five alternate host species grown in the greenhouse (GH) and field in winter (November 2001 to March 2002) and summer (July to November 2002). Black area represents the number of inoculation sites with X. fastidiosa recovery; striped area is the number of bacteria-free inoculation sites. Diamonds (secondary y-axis) represent median $X$. fastidiosa populations in $\log _{10} \mathrm{CFU} / \mathrm{g}$. 
populations were not measured immediately after inoculation in this study, an estimated $10^{6} \mathrm{CFU}$ of $X$. fastidiosa were introduced by each mechanical inoculation, which had lower infection rates than G. atropunctata inoculation. In contrast, few bacteria are required for infection by sharpshooters, since G. atropunctata can infect plants even when the population of bacteria in their mouthparts is below detectable levels (15).

This study showed that $X$. fastidiosa growth was markedly affected by environmental conditions. Although it was impossible to account for the impact of temperature alone in field experiments, temperature is likely a major driver or limiter of bacterial growth. For a subtropical and tropical pathogen, $X$. fastidiosa has an unexpectedly low maximum temperature for indefinite survival, $34^{\circ} \mathrm{C}$ (10). In this study, summer field temperatures were generally higher than the optimal growth temperature for $X$. fastidiosa and sometimes higher than the growth limiting temperature of $34^{\circ} \mathrm{C}$. This may explain the lower populations of $X$. fastidiosa that we detected in summer field plants compared with plants maintained in the greenhouse. Cool but above-freezing $\left(5^{\circ} \mathrm{C}\right)$ temperatures also decreased viable populations of $X$. fastidiosa (10), consistent with our findings that $X$. fastidiosa-inoculated plants in the same cohort reached much lower populations in winter field conditions than did plants held in greenhouse conditions optimal for $X$. fastidiosa growth.

Alternate host studies utilizing enzymelinked immunosorbent assays (27) or polymerase chain reaction (5) have identified plants harboring $X$. fastidiosa in the field, but population estimates in field-grown plants are needed to estimate their importance as sources of $X$. fastidiosa for vectors. In our summer field study, all species grown in the greenhouse developed $X$. fastidiosa populations greater than $10^{6}$ CFU/g, but similar populations were reached only in prickly lettuce in the fieldgrown plants. Field-grown common sunflower and cocklebur also supported $X$. fastidiosa populations around $10^{5} \mathrm{CFU} / \mathrm{g}$, 10 times greater than the threshold for sharpshooter acquisition of $X$. fastidiosa from grape (17). In winter tests, $X$. fastidiosa populations in field-grown fava bean and poison hemlock were also between $10^{4}$ and $10^{5} \mathrm{CFU} / \mathrm{g}$, while prickly lettuce did not support populations sufficient for sharpshooter acquisition. Further study is needed to determine factors governing systemic movement, even in grape, where it may vary with time of year (9) and variety (25).

Our study reinforces the need for weed control in irrigation ditches and roadsides adjacent to vineyards, in regions with chronic Pierce's disease and established populations of sharpshooters, especially in warm weather. Five species tested in this study have characteristics that could make them important in the spread of $X$. fastidiosa under field conditions, depending on vector populations. Common sunflower, annual bur-sage, common morning glory, poison hemlock, and fava bean (a cover crop plant) had at least $60 \%$ of insects survive the testing interval, supported bacterial populations of $10^{6} \mathrm{CFU} / \mathrm{g}$ or greater, and had systemic movement beyond inoculation sites. In contrast, cheeseweed and sowthistle have been observed as feeding hosts of $H$. coagulata (A. Purcell, unpublished data), but our studies indicate that these two plant species are unlikely to support adequate populations of the bacterium for frequent vector acquisition.

\section{ACKNOWLEDGMENTS}

We thank J. M. Hashim and P. Schrader for assistance at the Kern County Cooperative Extension office. D. Chiniquy, A. Dominguez, R. Mann, E. Norberg, and C. Y. Tung provided greenhouse or laboratory assistance at U.C. Berkeley. This research was supported by grants from the KernTulare Pierce's Disease and Glassy-winged Sharpshooter Task Force and the California Department of Food and Agriculture Pierce's Disease and Glassy-winged Sharpshooter Board.

\section{LITERATURE CITED}

1. Almeida, R. P. P., and Purcell, A. H. 2003. Biological traits of Xylella fastidiosa strains from grapes and almonds. Appl. Environ. Microbiol. 69:7447-7452.

2. Almeida, R. P. P., and Purcell, A. H. 2003. Transmission of Xylella fastidiosa to grapevines by Homalodisca coagulata. J. Econ. Entomol. 96:264-271.

3. Anonymous. 1999. The Growers Weed Identification Handbook. Univ. Calif. Div. Agric. Natl. Resources Publ. no. 4030.

4. Blua, M. J., Phillips, P. A., and Redak, R. A. 1999. A new sharpshooter threatens both crops and ornamentals. Calif. Agric. 53:22-25.

5. Costa, H. S., Raetz, E., Pinckard, T. R., Gispert, C., Hernandez-Martinez, R., Dumenyo, C. K., and Cooksey, D. A. 2004. Plant hosts of Xylella fastidiosa in and near southern California vineyards. Plant Dis. 88:1255-1261.

6. Davis, M. J., Purcell, A. H., and Thomson, S. V. 1980. Isolation media for the Pierce's disease bacterium. Phytopathology 70:425-429.

7. Davis, M. J., Raju, B. C., Brlansky, R. H., Lee, R. F., Timmer, L. W., Norris, R. C., and McCoy, R. E. 1983. Periwinkle wilt bacterium: Axenic culture, pathogenicity, and relationships to other gram-negative, xylem-inhabiting bacteria. Phytopathology 73:1510-1515.

8. Epstein, E. 1972. Mineral Nutrition of Plants: Principles and Perspectives. John Wiley \& Sons, New York.

9. Feil, H., Feil, W. S., and Purcell, A. H. 2003. Effects of date of inoculation on the withinplant movement of Xylella fastidiosa and persistence of Pierce's disease within field grapevines. Phytopathology 93:244-251.

10. Feil, H., and Purcell, A. H. 2001. Temperaturedependent growth and survival of Xylella fastidiosa in vitro and in potted grapevines. Plant Dis. 85:1230-1234.

11. Freitag, J. H. 1951. Host range of the Pierce's disease virus of grapes as determined by insect transmission. Phytopathology 41:920-931.
12. Freitag, J. H., and Frazier, N. W. 1954. Natural infectivity of leafhopper vectors of Pierce's disease virus of grape in California. Phytopathology 44:7-11.

13. Hendson, M., Purcell, A. H., Chen, D., Smart, C., Guilhabert, M., and Kirkpatrick, B. 2001. Genetic diversity of Pierce's disease strains and other pathotypes of Xylella fastidiosa. Appl. Environ. Microbiol. 67:895-903.

14. Hickman, J. C., ed. 1993. The Jepson Manual: Higher Plants of California, 2nd ed. University of California Press, Berkeley.

15. Hill, B. L., and Purcell, A. H. 1995. Acquisition and retention of Xylella fastidiosa by an efficient vector, Graphocephala atropunctata. Phytopathology 85:209-212.

16. Hill, B. L., and Purcell, A. H. 1995. Multiplication and movement of Xylella fastidiosa within grapevine and four other plants. Phytopathology 85:1368-1372.

17. Hill, B. L., and Purcell, A. H. 1997. Populations of Xylella fastidiosa in plants required for transmission by an efficient vector. Phytopathology 87:1197-1201.

18. Hopkins, D. L. 1976. Pierce's disease of grapevines. Am. Wine Soc. 8:26-27.

19. Hopkins, D. L. 1985. Effects of plant growth regulators on development of Pierce's disease symptoms in grape. Plant Dis. 69:944-946.

20. Hopkins, D. L., and Adlerz, W. C. 1988. Natural hosts of Xylella fastidiosa in Florida. Plant Dis. 72:429-431.

21. Houston, B. R., Esau, K., and Hewitt, W. B. 1947. The mode of vector feeding and the tissues involved in the transmission of Pierce's disease virus in grape and alfalfa. Phytopathology 37:247-253.

22. Purcell, A. H. 1976. Seasonal changes in host plant preference by the blue-green sharpshooter (Hordnia circellata). Pan-Pac. Entomol. 52:33-37.

23. Purcell, A. H. 1980. Environmental therapy for Pierce's disease of grapevines. Plant Dis. 64:388-390.

24. Purcell, A. H., and Finlay, A. 1979. Evidence for noncirculative transmission of Pierce's disease bacterium by sharpshooter leafhoppers. Phytopathology 69:393-395.

25. Purcell, A. H. 1981. Vector preference and inoculation efficiency as components of resistance to Pierce's disease in European grape cultivars. Phytopathology. 71:429-435.

26. Purcell, A. H., and Saunders, S. R. 1999. Fate of Pierce's disease strains of Xylella fastidiosa in common riparian plants in California. Plant Dis. 83:825-830.

27. Raju, B. C., Goheen, A. C., and Frazier, N. W. 1983. Occurrence of Pierce's disease bacteria in plants and vectors in California. Phytopathology 73:1309-1313.

28. Redak, R. A., Purcell, A. H., Lopes, J. R. S., Blua, M. J., Mizell, R. F., III, and Andersen, P. C. 2004. The biology of xylem fluid-feeding insect vectors of Xylella fastidiosa and their relation to disease epidemiology. Annu. Rev. Entomol. 49:243-270.

29. Severin, H. P. 1949. Life history of the bluegreen sharpshooter, Neokolla circellata. Hilgardia 19:187-189.

30. Severin, H. P. 1949. Transmission of the virus of Pierce's disease of grapevines by leafhoppers. Hilgardia 19:190-206.

31. Severin, H. P. 1950. Spittle-insect vectors of Pierce's disease virus. Hilgardia 19:357-381

32. Turner, W. F., and Pollard, H. N. 1959. Life history and behavior of five vectors of Phony Peach disease. U.S. Dep. Agric. Tech. Bull. 1188.

33. Zimmermann, M. H. 1983. Xylem structure and the ascent of sap (Springer series in wood science, v.1). Springer-Verlag, Berlin. pp. 31, 76. 